\title{
Organic and inorganic carbon in the topsoil of the Mongolian and Tibetan grasslands: pattern, control and implications
}

\author{
Y. Shi ${ }^{1}$, F. Baumann ${ }^{2}$, Y. Ma ${ }^{1}$, C. Song ${ }^{1,}{ }^{*}$, P. Kühn ${ }^{2}$, T. Scholten ${ }^{2}$, and J.-S. He ${ }^{3}$ \\ ${ }^{1}$ Department of Ecology, College of Urban and Environmental Sciences, and Key Laboratory for Earth Surface \\ Processes of the Ministry of Education, Peking University, 5 Yiheyuan Rd., 100871 Beijing, China \\ ${ }^{2}$ Department of Geoscience, Physical Geography and Soil Science, University of Tuebingen, \\ Ruemelinstrasse 19-23, 72070 Tuebingen, Germany \\ ${ }^{3}$ Key Laboratory of Adaptation and Evolution of Plateau Biota, Northwest Institute of Plateau Biology, \\ Chinese Academy of Sciences, 23 Xinning Rd., 810008 Xining, China \\ *now at: Department of Ecology and Evolutionary Biology, University of Kansas, Lawrence, KS 66045, USA
}

Correspondence to: J.-S. He (jshe@pku.edu.cn)

Received: 11 January 2012 - Published in Biogeosciences Discuss.: 15 February 2012

Revised: 18 May 2012 - Accepted: 27 May 2012 - Published: 27 June 2012

\begin{abstract}
Soil carbon (C) is the largest C pool in the terrestrial biosphere and includes both inorganic and organic components. Studying patterns and controls of soil C help us to understand and estimate potential responses of soil $\mathrm{C}$ to global change in the future. Here we analyzed topsoil data of 81 sites obtained from a regional survey across grasslands in the Inner Mongolia and on the Tibetan Plateau during 20062007 , attempting to find the patterns and controls of soil inorganic carbon (SIC) and soil organic carbon (SOC). The averages of inorganic and organic carbon in the topsoil $(0-20 \mathrm{~cm})$ across the study region were $0.38 \%$ and $3.63 \%$, ranging between $0.00-2.92 \%$ and $0.32-26.17 \%$ respectively. Both SIC and SOC in the Tibetan grasslands $(0.51 \%$ and $5.24 \%$ respectively) were higher than those in the Inner Mongolian grasslands $(0.21 \%$ and $1.61 \%)$. Regression tree analyses showed that the spatial pattern of SIC and SOC were controlled by different factors. Chemical and physical processes of soil formation drive the spatial pattern of SIC, while biotic processes drive the spatial pattern of SOC. SIC was controlled by soil acidification and other processes depending on soil $\mathrm{pH}$. Vegetation type is the most important variable driving the spatial pattern of SOC. According to our models, given the acidification rate in Chinese grassland soils in the future is the same as that in Chinese cropland soils during the past two decades: 0.27 and 0.48 units per $20 \mathrm{yr}$ in the Inner Mongolian grasslands and the Tibetan grasslands respectively, it will lead to a $30 \%$ and $53 \%$ decrease in SIC in
\end{abstract}

the Inner Mongolian grasslands and the Tibetan grasslands respectively. However, negative relationship between soil $\mathrm{pH}$ and SOC suggests that acidification will inhibit decomposition of SOC, thus will not lead to a significant general loss of carbon from soils in these regions.

\section{Introduction}

The importance of soil carbon (C) in global $\mathrm{C}$ cycling has received considerable attention in recent decades (Schulze and Freibauer, 2005; Trumbore and Czimczik, 2008; Schlesinger and Andrews, 2000; Lal, 2004a). A soil C pool comprises two distinct components: soil organic carbon (SOC) and soil inorganic carbon (SIC). The latter includes lithogenic inorganic carbon (LIC), which comes from parent material, and pedogenic inorganic carbon (PIC), which is formed through the dissolution and precipitation of carbonate parent material. On a global scale, the estimated size of SOC in the 1-m depth is 1500 to $1600 \mathrm{Pg}$ (Lal, 2004b; Monger and Gallegos, 2000; Batjes, 1996), and the size of SIC is 695 to $1738 \mathrm{Pg}$ (Batjes, 1996; Eswaran et al., 1995).

$\mathrm{C}$ flux between the atmosphere and terrestrial ecosystems involves both SOC and SIC. The C flux between SOC pools and the atmosphere depends on biomass production, organic materials input and soil respiration (Schlesinger and Andrews, 2000; Valentini et al., 2000). SIC pools exchange C 
with the atmosphere through a series of physical and chemical reaction, such as $\mathrm{C}$ sequestration by carbonate formation or $\mathrm{CO}_{2}$ release by acidification and leaching (Lal and Kimble, 2000; Lal, 2008; Ouyang et al., 2008). Given that global change has altered temperature, precipitation, nitrogen availability and many other environmental factors (Rockström et al., 2009; Vitousek, 1994), these changes are most likely to have great impact on soil carbon. As the largest $\mathrm{C}$ pool in terrestrial biosphere, even a minor change in soil carbon stocks could result in a significant alteration of atmospheric $\mathrm{CO}_{2}$ concentration (Davidson and Janssens, 2006; Trumbore and Czimczik, 2008). Therefore, both SIC and SOC pools should be considered in order to more accurately predict future soil carbon dynamics.

In arid and semiarid regions, which cover as much as onethird of the Earth's surface, SIC pools and their dynamics are important as the rate of accumulation of SIC is generally higher than in other biomes (Lal, 2008). Grasslands are one of the most widespread ecosystems in arid and semiarid regions, containing about $20 \%$ of global soil C stocks (Jobbagy and Jackson, 2000; Scurlock and Hall, 1998; Wang and Fang, 2009). Grasslands cover more than $40 \%$ of China's land surface, ranging from temperate grasslands in arid/semi-arid regions to alpine grasslands on the Tibetan Plateau (Kang et al., 2007; Yang et al., 2010b; He et al., 2009). Because of the large spatial extend, Chinese grasslands have significant effects on regional and global carbon cycles $(\mathrm{Ni}, 2002$; Yang et al., 2010b). Moreover, Chinese grasslands face rapid environmental changes (Kang et al., 2007). In recent years, many studies have been conducted to investigate the pattern, controls and dynamic of SOC (e.g. Ni, 2002; Yang et al., 2010b; Wu et al., 2003; Yu et al., 2007; Xie et al., 2007; Baumann et al., 2009) as well as SIC (e.g. Yang et al., 2010a; Mi et al., 2008; Feng et al., 2002) in Chinese grasslands. SOC stocks are reported to range from $37.7 \mathrm{Pg}$ (Xie et al., 2007) to 41.0 Pg (Ni, 2002) in Chinese grasslands, and about 16.7 Pg in northern China's grasslands (Yang et al., 2010b). On the scale of the whole of China, SOC densities are significantly influenced by temperature (Xie et al., 2007), while soil moisture and texture control SOC density in the Tibetan grasslands (Yang et al., 2008; Baumann et al., 2009). For SIC, total stocks of the top $1 \mathrm{~m}$ are estimated to vary from $53.3 \mathrm{Pg}$ to 77.9 Pg (Wu et al., 2009; Mi et al., 2008; Li et al., 2007) in China. Yang et al. (2010a) estimated the SIC stock of the Tibetan grasslands to $15.2 \mathrm{Pg}$. Temperature and precipitation both show significant relationships with SIC density (Li et al., 2007; Mi et al., 2008; Yang et al., 2010a).

However, there are still some uncertainties evident in recent studies. Most of the researches focused on mean soil carbon stocks for soil at depths of $1 \mathrm{~m}$ or more, but little work, especially for SIC, has been devoted to investigate the patterns, controls and dynamics of carbon in the topsoil. The topsoil is the component of the soil system showing most rapid responses to environmental changes, such as alterations in temperature, precipitation and nitrogen deposition (Liao et al., 2009; Song et al., 2005). Changes in the topsoil are particularly important for exploring ecosystem response and functioning (Franzluebbers and Stuedemann, 2010). Moreover, recent studies spent large efforts in determining patterns, controls and dynamics of SOC, but there is less attention drawn on SIC in general (Eswaran et al., 2000; Mi et al., 2008). Consequently, we cannot simply use results of these studies to predict potential responses of soil carbon to future global changes. Further, some recent studies calculated SIC as the difference between soil total carbon (STC) and SOC (e.g. Yang et al., 2010a; Mikhailova and Post, 2006). However, the proportions of carbonates in soil total carbon are usually small (Chatterjee et al., 2009), thus this method without the direct measurement of SIC could produce a large relative error. Therefore, studies focused on SIC based on measured data help us to reduce the uncertainties of previous studies and to predict response of soil carbon to global changes.

In this study, we analyzed the topsoil data of 81 sites obtained from a regional survey across grasslands in Inner Mongolia and the Tibetan Plateau during 2006-2007. We attempt (1) to investigate the large-scale patterns of inorganic and organic carbon in the topsoil of grasslands in Inner Mongolia and on the Tibetan Plateau, (2) to examine the changes of SIC and SOC along naturally occurring environmental gradients in order to identify key controlling factors for SIC and SOC contents, and (3) to estimate potential responses of inorganic and organic carbon in the topsoil related to soil acidification.

\section{Materials and methods}

\subsection{Study sites}

This study was conducted in temperate grasslands in the Inner Mongolia and alpine grasslands on the Tibetan Plateau, during two expeditions in late July and early August of 2006 and 2007. We selected 81 sites along an approximately $4000 \mathrm{~km}$ long transect (longitude from 90.80 to $120.12^{\circ} \mathrm{E}$, latitude from 30.31 to $50.19^{\circ} \mathrm{N}$, and altitude from 549 to $5105 \mathrm{~m}$ a.s.l.) for soil and plant community sampling (Table 1, Fig. 1). Mean annual temperature (MAT) ranges from -5.8 to $4.1{ }^{\circ} \mathrm{C}$ and mean annual precipitation (MAP) ranges from 148 to $604 \mathrm{~mm}$. The sites along the transect represent natural zonal grassland vegetation, including the five main vegetation types: meadow steppe, typical steppe, desert steppe, alpine steppe and alpine meadow. Field sites were selected by visual inspection of the vegetation, aiming to select sampling sites subject to minimal grazing and other anthropogenic disturbances. 
Table 1. Description of the study regions. Mean annual temperature (MAT), mean annual precipitation (MAP), growing season temperature (GST), growing season precipitation (GSP), Averaged topsoil $\mathrm{pH}$, soil bulk density (SBD), soil moisture (SM) and soil total nitrogen (STN) of the sampling sites are shown.

\begin{tabular}{lrrr}
\hline & Overall & $\begin{array}{r}\text { Inner Mongolian } \\
\text { grasslands }\end{array}$ & $\begin{array}{r}\text { Tibetan } \\
\text { grasslands }\end{array}$ \\
\hline No. of site & 81 & 36 & 45 \\
Longitude $\left({ }^{\circ} \mathrm{E}\right)$ & $90.80-120.12$ & $111.83-120.12$ & $90.80-101.48$ \\
Latitude $\left({ }^{\circ} \mathrm{N}\right)$ & $30.31-50.19$ & $41.79-50.19$ & $30.31-37.28$ \\
Altitude $(\mathrm{m})$ & $549-5105$ & $549-1418$ & $2925-5105$ \\
MAT $\left({ }^{\circ} \mathrm{C}\right)$ & $-5.8-4.1$ & $-2.6-4.1$ & $-5.8-2.6$ \\
$\mathrm{GST}\left({ }^{\circ} \mathrm{C}\right)$ & $1.5-16.9$ & $11.2-16.9$ & $1.5-11$ \\
$\mathrm{MAP}\left(\mathrm{mm} \mathrm{yr}^{-1}\right)$ & $148-604$ & $148-436$ & $218-604$ \\
$\mathrm{GSP}\left(\mathrm{mm} \mathrm{yr}^{-1}\right)$ & $115-402$ & $115-343$ & $133-402$ \\
Soil pH & $5.2-8.2$ & $5.7-8.2$ & $5.2-7.6$ \\
$\mathrm{SBD}\left(\mathrm{g} \mathrm{cm}^{-3}\right)$ & $0.25-1.63$ & $0.94-1.63$ & $0.25-1.43$ \\
$\mathrm{SM}(\mathrm{V} / \mathrm{V} \%)$ & $0.73-68.11$ & $2.04-16.10$ & $0.73-68.11$ \\
$\mathrm{STN}(\mathrm{g} / \mathrm{g} \mathrm{\%})$ & $0.04-1.52$ & $0.05-0.45$ & $0.04-1.52$ \\
\hline
\end{tabular}

\subsection{Soil and biomass survey}

Detailed field investigations included soil profile description according to FAO (2006) and IUSS Working Group WRB (2006). Soil sampling was split into two parts: schematic soil sampling by drilling at three depth increments $(0-5,5-10$, and $10-20 \mathrm{~cm})$ for SIC and SOC analyses, as well as volumetric sampling using a standard container $\left(100 \mathrm{~cm}^{3}\right.$ in volume) at equal depths for soil bulk density (SBD) and gravimetric water content (equalling to soil moisture, SM) determination. The sampling protocol is described in Baumann et al. (2009).

Soil samples were air-dried, all live root material was removed and the remaining soil was grounded using a ball mill (NM200, Retsch, Germany). We measured soil inorganic carbon (SIC) volumetrically using an inorganic carbon analyzer (Calcimeter 08.53, Eijkelkamp, Netherland). Soil total carbon (STC) was measured by dry combustion using an elemental analyzer (VARIO EL III, Elementar, Hanau, Germany) with a combustion temperature of $1150^{\circ} \mathrm{C}$ and a reduction temperature of $850^{\circ} \mathrm{C}$. Soil organic carbon (SOC) was calculated as the difference between STC and SIC. The average concentration of SIC, SOC and STC of the top $20 \mathrm{~cm}$ was calculated using the data from the three layers with soil bulk density, and this average value was used as site level data. Soil $\mathrm{pH}$ was determined in both $0.01 \mathrm{M} \mathrm{CaCl}_{2}$ and double distilled water potentiometrically. Results from these two methods showed a very strong linear relationship. Since using a $\mathrm{CaCl}_{2}$ solution gives better repeatable results (Brady and Weil, 2002), the $\mathrm{pH}$ data from a $\mathrm{CaCl}_{2}$ solution were used in the model. Soil total nitrogen was also determined using an elemental analyzer (PE 2400 II CHN elemental analyzer, Perkin-Elmer, Boston, Massachusetts, USA).

Additionally, we measured aboveground biomass (AGB) in three plots $\left(1 \times 1 \mathrm{~m}^{2}\right)$ and belowground biomass (BGB)

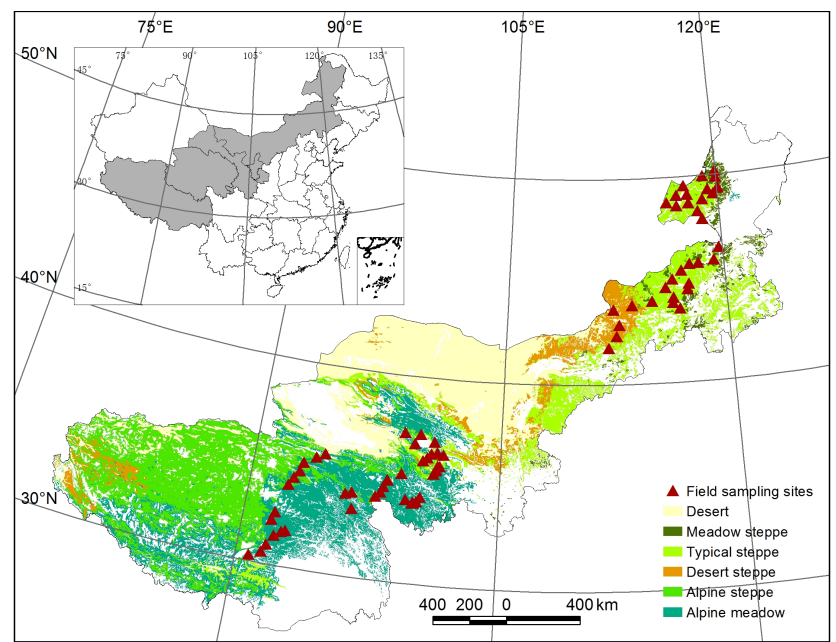

Fig. 1. Vegetation map of Chinese grasslands and location of sampling sites (1:1000 000) (Chinese Academy of Sciences, 2001).

in three soil pits $\left(0.5 \times 0.5 \mathrm{~m}^{2}\right)$ at each site. Biomass was measured by oven-drying at $60^{\circ} \mathrm{C}$ to a constant weight and weighting to the nearest $0.1 \mathrm{~g}$.

\subsection{Climate data and statistical analyses}

Climate data for each site was calculated based on linear models using latitude, longitude and altitude as predictors from 55-yr average temperature and precipitation records (1951-2005) at 680 climate stations across China (Fang et al., 2001; He et al., 2009). The calculation of potential evapotranspiration (PE) and actual evapotranspiration (AE) were based on Thornthwaite's method (Thornthwaite, 1948).

We used one-way ANOVA with Turkey's post hoc test to compare the effects of region, vegetation type, and soil depth on SIC, SOC and the ratio of SIC to STC (SIC/STC). We conducted classification and regression tree (CART) analyses, which can deal with both categorical and continuous variables simultaneously (Qian, 2009), to detect important variables influencing the patterns of SIC, SOC and SIC/STC. We selected the complexity parameter as split criterion, and set the observations required for a split search at 15. Climatic factors, including MAT, MAP, growing season temperature (GST, from April to August), growing season precipitation (GSP), AE, PE, as well as biotic factors including vegetation type (VT), AGB, and BGB were used in the tree models (Table 4). Since soil $\mathrm{pH}, \mathrm{SM}, \mathrm{CO}_{2}$ partial pressure and water deficiency also influenced SIC, soil $\mathrm{pH}, \mathrm{SM}$, altitude (proxy of $\mathrm{CO}_{2}$ partial pressure) as well as the ratio of MAP to $\mathrm{PE}$ (MAP/PE, an index of water deficiency) were incorporated into the CART analysis when we analysed SIC and SIC/STC. We did not include the overall grazing intensity as covariate in our model because our approach focuses on landscape scale stretching across regions with particular climate and geomorphology. Grazing patterns and grazing intensities 
are supposed to vary greatly in such diverse regions. Official data cannot be used to reflect the pattern since they are bound to county and provincial boundaries. Finally, for estimating the change of carbonates of the topsoil in the Inner Mongolian and Tibetan grasslands under the background of soil acidification, we built ordinary linear regression models for SIC and SIC/STC, using the most powerful explanatory variables in the CART analysis. SIC, SOC and SIC/STC were $\log$ transformation to achieve normal distribution (Fig. 2). All statistical analyses were performed using R 2.3.0 (R Development Core Team, 2011). The classification and regression trees were developed using the $\mathrm{R}$ package rpart.

\section{Results}

\subsection{Overall patterns of SIC, SOC and SIC/STC}

Frequency distributions of SIC, SOC and SIC/STC did not deviate significantly from $\log$ normal distributions $(P>$ $0.05)$ neither at site level nor for each depth increment. At site level, the mean values of SIC, SOC and SIC/STC were $0.38 \%, 3.58 \%$ and 0.15 , ranging between $0.00-2.92 \%$, $0.32-26.34 \%$ and $0.00-0.65$, with CV of $1.36,1.19$ and 1.26 , respectively (Table 3 ). We did not find significant differences of SIC and SIC/STC among three soil depths $(P<0.05)$, while SOC in $0-5 \mathrm{~cm}$ was significantly higher than that in $10-$ $20 \mathrm{~cm}$.

At site level, inorganic and organic carbon in the topsoil differed remarkably between the Inner Mongolian and Tibetan grasslands. The means of both SIC and SOC in the Tibetan grasslands $(0.51 \%$ and $5.24 \%$ respectively) were higher $(P<0.01)$ than those in the Inner Mongolia grasslands $(0.21 \%$ and $1.61 \%)$. However, SIC/STC had no significant difference between the Tibetan grasslands and the Inner Mongolian grasslands $(0.18$ and $0.11, P=0.54)$. These patterns are also evident for the three soil depth increments (Table 3). Soil $\mathrm{pH}$ showed no significant difference between the two regions, while soils in the Tibetan grasslands generally accounted for higher soil total nitrogen and SM but lower SBD compared to the Inner Mongolian grasslands (Table 2).

On the whole, vegetation type had significant effects on SIC, SOC and SIC/STC $(P<0.01)$. Generally, inorganic carbon was higher in alpine steppe soils than in meadow steppe and typical steppe soils. Organic carbon was higher in alpine meadow soils compared to desert steppe soils. SIC/STC was highest in the alpine steppe and lowest in the alpine meadow (Table 3).

\subsection{Factors driving spatial variations of SIC and SOC}

We developed regression tree models for SIC, SOC and SIC/STC (Fig. 3a-c). All three trees were significantly different from a random tree $(P<0.05)$. The trees for SIC, SOC and SIC/STC explained $69 \%, 76 \%$, and $73 \%$ of the variance, respectively. Tree models revealed that the spatial
Table 2. Topsoil properties in the Inner Mongolian and Tibetan grasslands across sampling sites. Different letters indicate statistical significance at $P<0.05$. SBD $=$ soil bulk density; $\mathrm{SM}=$ soil moisture; $\mathrm{STN}=$ soil total nitrogen; $\mathrm{CV}=$ coefficient of variation.

\begin{tabular}{llrr}
\hline & & $\begin{array}{r}\text { Inner } \\
\text { Mongolian } \\
\text { grasslands }\end{array}$ & $\begin{array}{r}\text { Tibetan } \\
\text { grasslands }\end{array}$ \\
\hline Soil pH & Mean & 36 & 45 \\
& CV & $6.9 a$ & $6.8 a$ \\
& Range & $5.7-8.2$ & 0.09 \\
& $n$ & 36 & $4.2-7.6$ \\
\hline SBD $\left(\mathrm{g} \mathrm{cm}^{-3}\right)$ & Mean & $1.3 b$ & $0.95 a$ \\
& CV & 0.13 & 0.33 \\
& Range & $0.94-1.63$ & $0.25-1.43$ \\
\hline SM $(\mathrm{V} / \mathrm{V} \%)$ & $n$ & 32 & 44 \\
& Mean & $7.29 a$ & $20.95 b$ \\
& CV & 0.55 & 0.85 \\
& Range & $2.04-16.10$ & $0.73-68.11$ \\
\hline STN (g/g \%) & $n$ & 36 & 45 \\
& Mean & $0.17 a$ & $0.44 \mathrm{~b}$ \\
& CV & 0.54 & 0.81 \\
& Range & $0.05-0.45$ & $0.04-1.52$ \\
\hline
\end{tabular}

variations in SIC, SOC and SIC/STC were driven by very different factors (Table 4, Fig. 3).

For SIC (Fig. 3a), the tree model had an initial split on soil $\mathrm{pH}$ with a threshold of 7.0 , implying that soil $\mathrm{pH}$ was the most important variable explaining the spatial variation of SIC. As pH increases above this threshold, MAT and PE represent two thermal factors that became common to affect SIC contents, indicating a negative relationship between SIC and thermal condition. In areas with $\mathrm{pH}$ below 7.0, MAP and $\mathrm{SM}$, both reflecting water conditions, were included in the model: carbonate in the topsoil was typically lower on average in low-precipitation $\left(<465 \mathrm{~mm} \mathrm{yr}^{-1}\right)$ areas; in the areas with more precipitation, inorganic carbon was relatively high in soils with low moisture.

Vegetation type was the most important variable for SOC (Fig. 3b), explaining $49 \%$ of the variations of SOC. Steppe soils had much lower organic carbon content than meadow soils. In the steppe, only GSP influenced SOC, with a trend that SOC increased with GSP. In the meadow, AGB and PE were involved. Lower AGB $\left(<95.4 \mathrm{~g} \mathrm{~m}^{-2}\right)$ corresponded to lower SOC; but when AGB was above this threshold, SOC decreased with increasing of PE.

Soil $\mathrm{pH}$ was the initial split variable with a threshold of 7.0 for SIC/STC (Fig. 3c). When soil $\mathrm{pH}$ increases above this threshold, AGB and MAT enter the model, while SM and BGB enter the model when $\mathrm{pH}$ is below this threshold. These environmental factors impact the spatial pattern of SIC/STC through influencing SIC and/or SOC. 


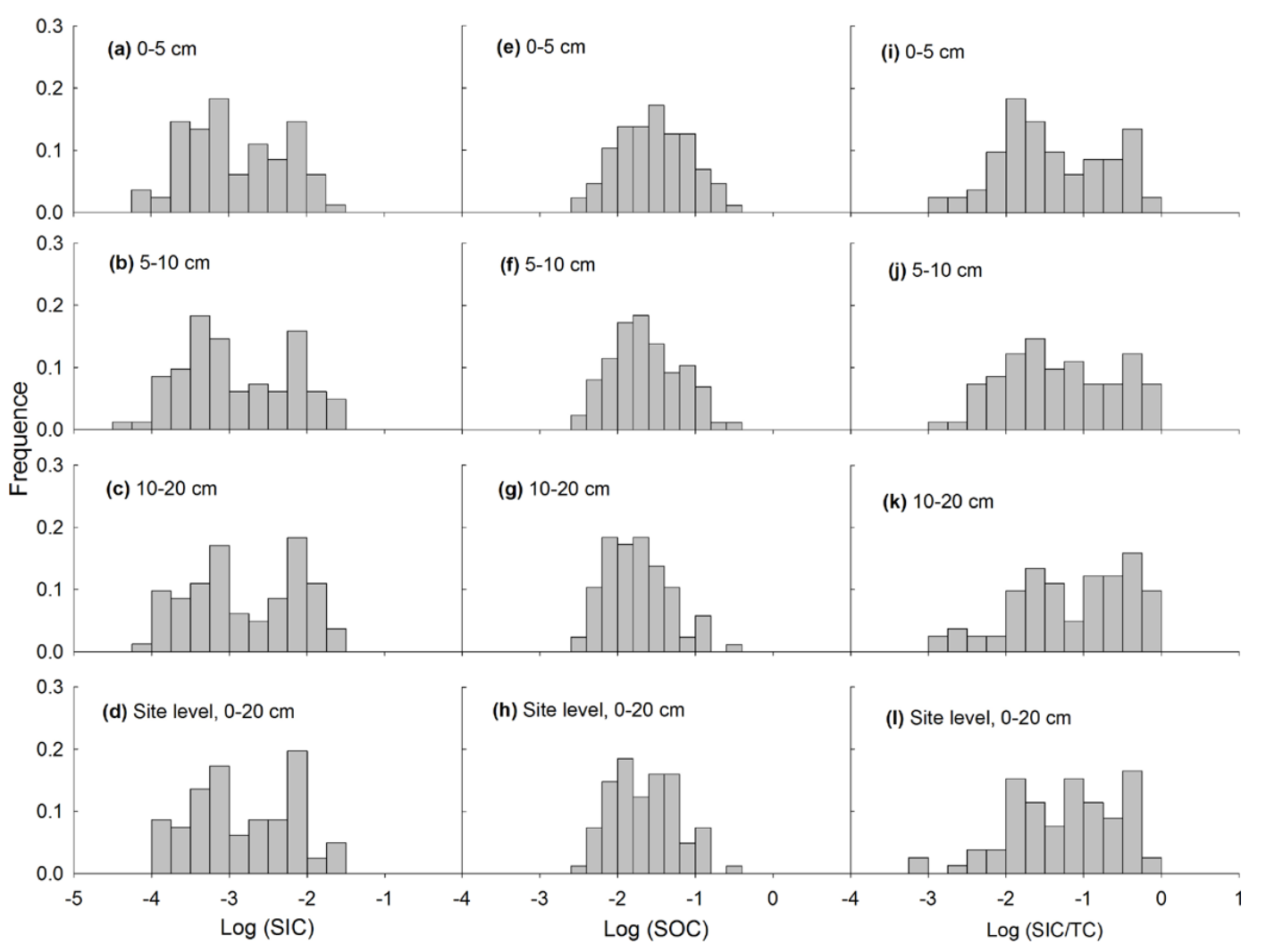

Fig. 2. Frequency distributions of SIC (a-d), SOC (e-h) and SIC/STC (i-l) in Chinese grasslands across all sampling sites at soil depths of 0-5 cm (a, e, i), 5-10 cm (b, f, j), 10-20 cm (c, g, k) and at site level $(\mathbf{d}, \mathbf{h}, \mathbf{l})$. All distributions have no significant differences compared with normal distribution at $P<0.05$.

\subsection{Empirical models for estimating the change of SIC}

Regression trees showed that soil $\mathrm{pH}$ was the most important variable driving the pattern of both SIC and SIC/STC. Therefore, we built linear regression models to predict SIC and SIC/STC from soil pH (Fig. 4a-b).

SIC and SIC/STC were both correlated with soil $\mathrm{pH}$ positively $(P<0.01)$. The model for SIC had a slope of 0.58 with an $R^{2}$ of 0.29 (Fig. 4a), while the model for SIC/STC had a slope of 0.75 with an $R^{2}$ of 0.43 (Fig. 4b). The analysis showed that it was adequate to estimate SIC with the models, considering the sample size and spatial pattern. The results of these empirical models showed that 1-unit decrease in soil $\mathrm{pH}$ would lead to $73 \%$ and $82 \%$ decrease in SIC and SIC/STC respectively.

Furthermore, SIC/STC decreases faster than SIC when soil $\mathrm{pH}$ goes down, suggesting that SOC may also be affected by soil acidity. Thus, we did linear regression analyses to test the relationship between SOC and soil $\mathrm{pH}$. The result showed a significant negative relationship between SOC and soil pH $(P<0.05)$, with a slope of -0.29 and an $R^{2}$ of 0.18 (Fig. 4c).

\section{Discussion}

\subsection{Higher SIC and SOC in the Tibetan grasslands}

Our results showed significantly higher concentrations for both SIC and SOC in the Tibetan grasslands than for those in the Inner Mongolian grasslands, at site level as well as for in each depth increment.

Across all the sites, SOC concentration is approximately 9 times as high as SIC concentration. The SIC content in our study, calculated with bulk density, had a mean value of $3.9 \mathrm{~kg} \mathrm{~m}^{-3}$ in $0-10 \mathrm{~cm}$ depth, which is lower than the average SIC content of $6 \mathrm{~kg} \mathrm{~m}^{-3}$ in the same depth increment in Chinese grasslands reported by Mi et al. (2008). Most likely, this is the case because the western Tibetan grasslands, which generally have higher SIC contents, were not included in our studies. Yang et al. (2010a) reported an average inorganic carbon density of $5.7 \mathrm{~kg} \mathrm{~m}^{-2}$ in the top $30 \mathrm{~cm}$ soil of the Tibetan grasslands, equal to $19.0 \mathrm{~kg} \mathrm{~m}^{-3}$ in $0-30 \mathrm{~cm}$ soil depth. Even considering different focused soil depth, their result is still much higher than the results of Mi et al. (2008) and the current study. The average organic carbon concentration in $0-20 \mathrm{~cm}$ soil depth in our study is $38.4 \mathrm{~g} \mathrm{~kg}^{-1}$, close to the 
(a) $\mathrm{R}^{2}=0.69, P<0.05$

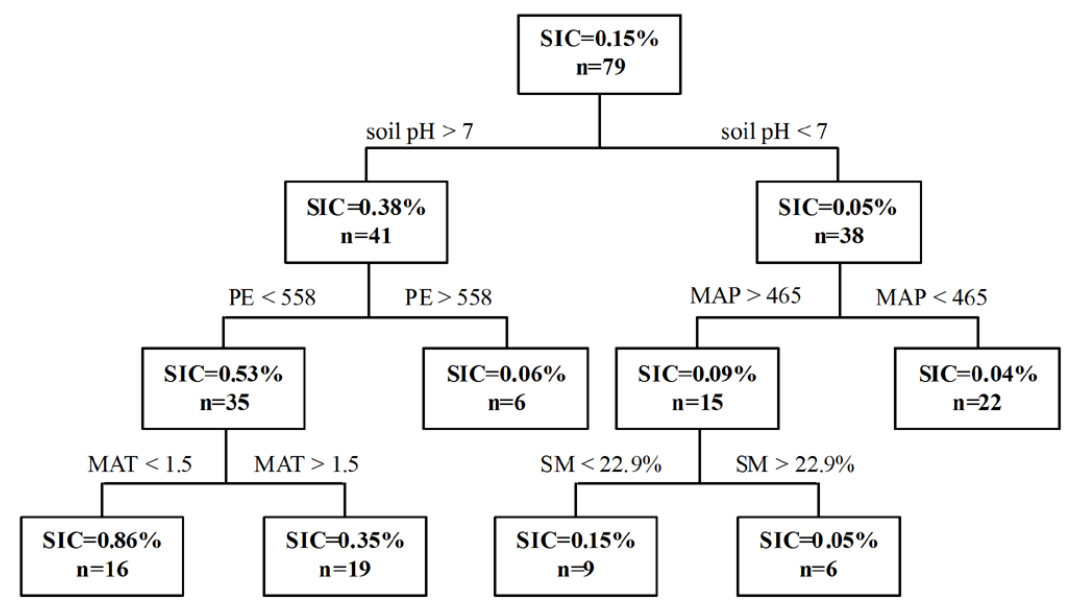

(b) $\mathrm{R}^{2}=0.79, P<0.05$

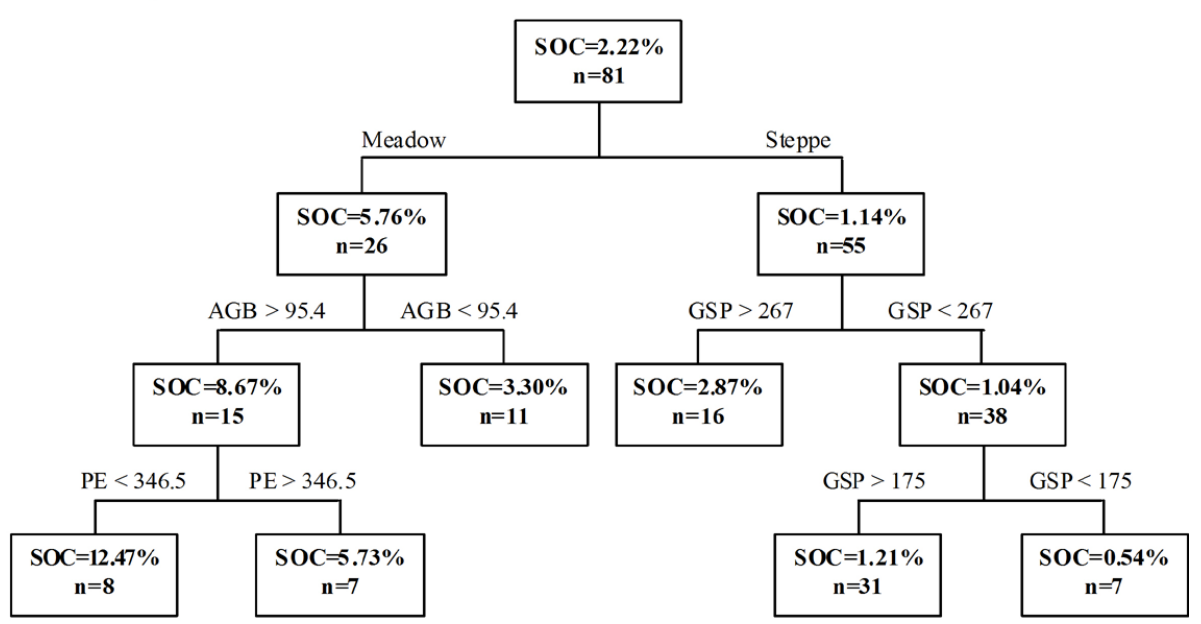

(c) $\mathrm{R}^{2}=0.73, P<0.05$

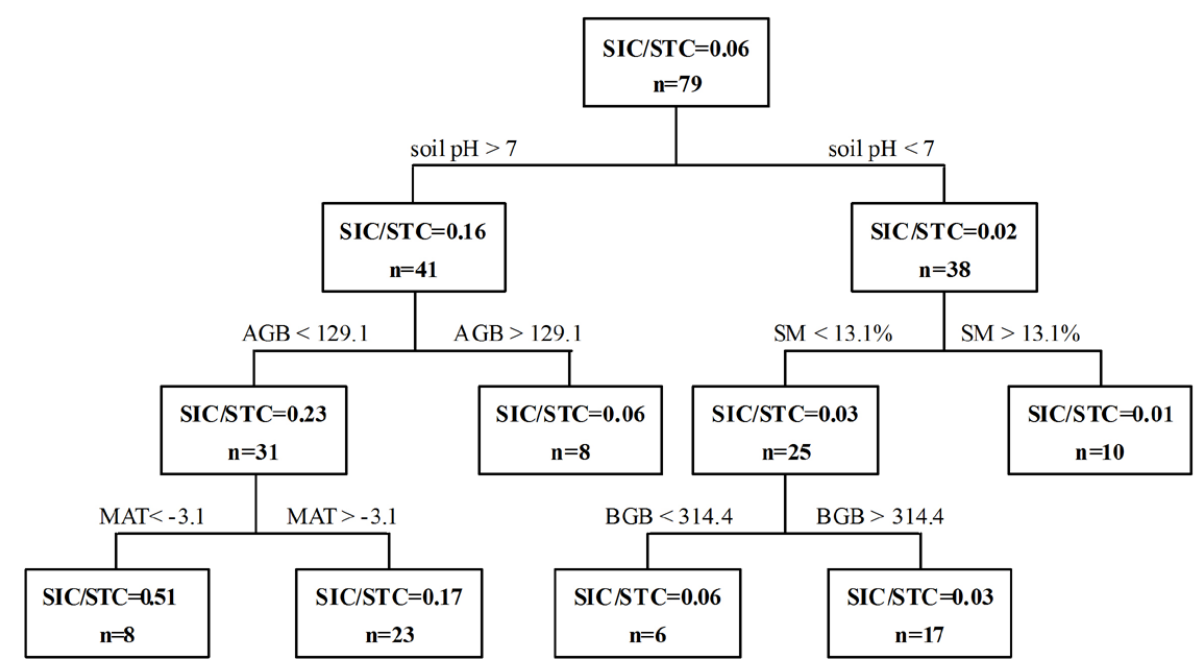

Fig. 3. Classification and regression trees of SIC (a), SOC (b), SIC/ STC (c). Branches are labelled with criteria used to segregate data. Values in terminal nodes represent mean soil SIC (a), SOC (b) and SIC/STC (c) of sites $(0-20 \mathrm{~cm})$ grouped within the cluster. 
Table 3. Statistical description of soil inorganic carbon (SIC), soil organic carbon (SOC) content and SIC to soil total carbon ratio (SIC/STC) in each depth increment in different regions and vegetation types. Different letters indicate statistical significance at $P<0.05$. $\mathrm{CV}=$ coefficient of variation.

\begin{tabular}{|c|c|c|c|c|c|c|c|c|c|c|c|c|c|}
\hline & & \multicolumn{4}{|c|}{$\operatorname{SIC}(\%)$} & \multicolumn{4}{|c|}{ SOC (\%) } & \multicolumn{4}{|c|}{ SIC/STC } \\
\hline & & $0-5 \mathrm{~cm}$ & $5-10 \mathrm{~cm}$ & $10-20 \mathrm{~cm}$ & Site level & $0-5 \mathrm{~cm}$ & $5-10 \mathrm{~cm}$ & $10-20 \mathrm{~cm}$ & Site level & $0-5 \mathrm{~cm}$ & $5-10 \mathrm{~cm}$ & $10-20 \mathrm{~cm}$ & Site level \\
\hline \multirow[t]{4}{*}{ Overall } & Mean & 0.31 & 0.35 & 0.44 & 0.38 & 4.78 & 3.74 & 2.92 & 3.58 & 0.11 & 0.13 & 0.18 & 0.15 \\
\hline & $\mathrm{CV}$ & 1.49 & 1.52 & 1.33 & 1.36 & 1.08 & 1.17 & 1.32 & 1.19 & 1.46 & 1.43 & 1.16 & 1.26 \\
\hline & Range & $0.00-1.92$ & $0.00-2.28$ & $0.00-2.61$ & $0.00-2.20$ & $0.29-27.51$ & $0.30-25.43$ & $0.28-26.00$ & $0.32-26.34$ & $0.00-0.66$ & $0.00-0.66$ & $0.00-0.74$ & $0.00-0.65$ \\
\hline & $n$ & 87 & 87 & 87 & 81 & 87 & 87 & 87 & 81 & 87 & 87 & 87 & 81 \\
\hline \multicolumn{14}{|l|}{ Region } \\
\hline \multirow{4}{*}{$\begin{array}{l}\text { Inner Mongolian } \\
\text { grasslands }\end{array}$} & Mean & $0.14 a$ & $0.18 a$ & $0.25 a$ & $0.22 a$ & $2.23 a$ & $1.58 a$ & $1.26 a$ & $1.61 a$ & $0.07 a$ & $0.09 a$ & $0.14 a$ & $0.11 a$ \\
\hline & $\mathrm{CV}$ & 2.09 & 2.30 & 1.81 & 1.89 & 0.72 & 0.66 & 0.65 & 0.66 & 1.44 & 1.66 & 1.31 & 1.39 \\
\hline & Range & $0.01-1.59$ & $0.00-2.12$ & $0.01-2.37$ & $0.01-2.10$ & $0.29-7.54$ & $0.30-4.42$ & $0.28-3.60$ & $0.32-4.55$ & $0.00-0.39$ & $0.00-0.53$ & $0.00-0.65$ & $0.00-0.54$ \\
\hline & $n$ & 39 & 39 & 39 & 36 & 39 & 39 & 39 & 36 & 39 & 39 & 39 & 36 \\
\hline \multirow[t]{4}{*}{ Tibetan grasslands } & Mean & $0.45 b$ & $0.49 b$ & $0.58 b$ & $0.51 b$ & $6.84 b$ & $5.50 b$ & $4.27 b$ & $5.15 b$ & $0.15 a$ & $0.17 a$ & $0.21 a$ & $0.18 a$ \\
\hline & $\mathrm{CV}$ & 1.18 & 1.19 & 1.07 & 1.10 & 0.89 & 0.95 & 1.11 & 0.99 & 1.30 & 1.27 & 1.06 & 1.16 \\
\hline & Range & $0.00-1.92$ & $0.00-2.28$ & $0.00-2.61$ & $0.00-2.20$ & $0.41-27.51$ & $0.35-25.43$ & $0.45-26.00$ & $0.45-26.34$ & $0.00-0.66$ & $0.00-0.66$ & $0.00-0.74$ & $0.00-0.65$ \\
\hline & $n$ & 48 & 48 & 48 & 45 & 48 & 48 & 48 & 45 & 48 & 48 & 48 & 45 \\
\hline \multicolumn{14}{|l|}{ Vegetation type } \\
\hline \multirow[t]{4}{*}{ Meadow steppe } & Mean & $0.06 a b$ & $0.04 a b$ & $0.16 a b$ & $0.11 a$ & $3.21 b$ & $2.46 b$ & $2.04 b$ & $2.43 b$ & $0.03 a$ & $0.02 a$ & $0.09 a b$ & $0.06 a b$ \\
\hline & $\mathrm{CV}$ & 0.88 & 0.47 & 1.71 & 1.41 & 0.54 & 0.57 & 0.53 & 0.53 & 1.21 & 0.68 & 1.49 & 1.46 \\
\hline & Range & $0.02-0.19$ & $0.02-0.07$ & $0.01-0.78$ & $0.01-0.44$ & $0.88-5.29$ & $0.73-4.17$ & $0.59-3.60$ & $0.70-4.15$ & $0.00-0.11$ & $0.00-0.05$ & $0.00-0.37$ & $0.00-0.25$ \\
\hline & $n$ & 7 & 7 & 7 & 7 & 7 & 7 & 7 & 7 & 7 & 7 & 7 & 7 \\
\hline \multirow[t]{4}{*}{ Typical steppe } & Mean & $0.16 a$ & $0.21 a$ & $0.28 a$ & $0.24 a$ & $2.42 b$ & $1.64 a b$ & $1.25 a b$ & $1.65 a b$ & $0.05 a$ & $0.08 a$ & $0.12 a b$ & $0.09 a b$ \\
\hline & $\mathrm{CV}$ & 2.23 & 2.36 & 1.93 & 2.02 & 0.64 & 0.52 & 0.51 & 0.55 & 1.81 & 1.79 & 1.46 & 1.52 \\
\hline & Range & $0.01-1.59$ & $0.00-2.12$ & $0.01-2.37$ & $0.01-2.10$ & $0.69-7.54$ & $0.57-4.418$ & $0.48-3.51$ & $0.59-4.55$ & $0.00-0.39$ & $0.00-0.50$ & $0.01-0.63$ & $0.01-0.51$ \\
\hline & $n$ & 24 & 24 & 24 & 22 & 24 & 24 & 24 & 22 & 24 & 24 & 24 & 22 \\
\hline \multirow[t]{4}{*}{ Desert steppe } & Mean & $0.23 a b$ & $0.31 a b c$ & $0.44 a b$ & $0.39 a b$ & $1.07 a$ & $0.98 a$ & $0.80 a$ & $0.98 a$ & $0.17 b$ & $0.20 a b$ & $0.26 a b$ & $0.24 b c$ \\
\hline & $\mathrm{CV}$ & 1.08 & 1.19 & 1.11 & 1.00 & 0.89 & 0.82 & 0.75 & 0.73 & 0.81 & 0.95 & 0.75 & 0.79 \\
\hline & Range & $0.01-0.76$ & $0.01-0.92$ & $0.02-1.25$ & $0.01-0.94$ & $0.29-3.40$ & $0.30-2.96$ & $0.28-2.07$ & $0.32-2.62$ & $0.02-0.45$ & $0.02-0.53$ & $0.02-0.65$ & $0.02-0.54$ \\
\hline & $n$ & 10 & 10 & 10 & 9 & 10 & 10 & 10 & 9 & 10 & 10 & 10 & 9 \\
\hline \multirow[t]{4}{*}{ Alpine steppe } & Mean & $0.71 c$ & $0.76 c$ & $0.83 b$ & $0.78 b$ & $2.42 b$ & $2.07 a b$ & $1.80 \mathrm{~b}$ & $1.97 a b$ & $0.29 b$ & $0.30 b$ & $0.34 b$ & $0.32 c$ \\
\hline & $\mathrm{CV}$ & 0.82 & 0.90 & 0.89 & 0.88 & 0.72 & 0.63 & 0.61 & 0.65 & 0.75 & 0.77 & 0.68 & 0.69 \\
\hline & Range & $0.00-1.92$ & $0.04-2.28$ & $0.01-2.61$ & $0.02-2.20$ & $0.41-6.24$ & $0.35-4.33$ & $0.45-4.00$ & $0.45-4.19$ & $0.00-0.66$ & $0.01-0.66$ & $0.01-0.74$ & $0.01-0.65$ \\
\hline & $n$ & 18 & 18 & 18 & 17 & 18 & 18 & 18 & 17 & 18 & 18 & 18 & 17 \\
\hline \multirow[t]{4}{*}{ Alpine meadow } & Mean & $0.27 b$ & $0.31 b c$ & $0.39 a b$ & $0.30 a b$ & $10.02 c$ & $7.94 c$ & $6.03 c$ & $7.47 c$ & $0.05 a$ & $0.08 a$ & $0.11 a$ & $0.07 a$ \\
\hline & $\mathrm{CV}$ & 1.63 & 1.51 & 1.27 & 1.25 & 0.61 & 0.71 & 0.92 & 0.76 & 2.01 & 2.01 & 1.53 & 1.66 \\
\hline & Range & $0.00-1.698$ & $0.00-1.75$ & $0.00-1.71$ & $0.00-1.68$ & $1.07-27.51$ & $0.82-25.43$ & $0.69-26.00$ & $0.81-26.34$ & $0.00-0.40$ & $0.00-0.63$ & $0.00-0.67$ & $0.00-0.55$ \\
\hline & $n$ & 28 & 28 & 28 & 26 & 28 & 28 & 28 & 26 & 28 & 28 & 28 & 26 \\
\hline
\end{tabular}

average value of $38.5 \mathrm{~g} \mathrm{~kg}^{-1}$ in Chinese grasslands reported by Xie et al. (2007).

Differences in soil formation and climatic conditions between Inner Mongolian grasslands and the Tibetan grassland may contribute to the above-described patterns. The fact that there was no significant difference between soil $\mathrm{pH}$ in Inner Mongolian and Tibetan grasslands suggests that higher SIC in the Tibetan grasslands may be due to basically two other reasons. Firstly, compared with soils of the Inner Mongolian grasslands, soils of the Tibetan grasslands developed later thus parent material had stronger effects on soil characteristics, and carbonate migration is also lower (Xiong and $\mathrm{Li}, 1987)$. This would lead to higher LIC in the soil in the Tibetan grasslands. Secondly, due to higher elevation, $\mathrm{CO}_{2}$ partial pressure is lower in the Tibetan grasslands (Körner, 2003). Lower temperature also induces lower soil respiration thus lower $\mathrm{CO}_{2}$ partial pressure in the Tibetan grasslands soil (Kato et al., 2006). This influences the formation of pedogenic carbonate as presented in the following chemical equation:

$\mathrm{Ca}^{2+}+2 \mathrm{HCO}_{3}^{-} \leftrightarrow \mathrm{CaCO}_{3}+\mathrm{H}_{2} \mathrm{O}+\mathrm{CO}_{2}$
Consequently, lower $\mathrm{CO}_{2}$ partial pressure will move the equilibrium towards more precipitation of carbonate (Nordt et al., 2000), benefitting the formation of PIC. Although this chemical reaction is well known, no studies considered $\mathrm{CO}_{2}$ partial pressure as an important factor in determining the large-scale pattern of SIC. For the first time, our results showed that $\mathrm{CO}_{2}$ partial pressure may play a key role in shaping topsoil carbonates in extreme high altitudinal environments.

The pattern of SOC could be attributed to climatic differences between these two regions. Low temperature leads to slower decomposition rates (Wu et al., 2003; Xie et al., 2007; Kirschbaum, 1995), and high precipitation causes high vegetation productivity (Jobbagy and Jackson, 2000; Wynn et al., 2006; Callesen et al., 2003). In addition, high moisture, and especially temporal water saturation in the Tibetan grasslands due to the frozen ground, also leads to slower decomposition rates (Baumann et al., 2009). All these factors contribute to the accumulation of organic carbon in the topsoil of the Tibetan grasslands. 
Table 4. Variables included and selected in the regression tree analysis. Alt =altitude; MAT = mean annual temperature; GST = growing season temperature; $\mathrm{MAP}=$ mean annual precipitation; $\mathrm{GSP}=$ growing season precipitation; $\mathrm{PE}=$ potential evapotranspiration; $\mathrm{AE}=$ actual evapotranspiration; $\mathrm{AP} / \mathrm{PE}=$ the ratio of $\mathrm{MAP}$ to $\mathrm{PE} ; \mathrm{VT}=$ vegetation type; $\mathrm{AGB}=$ aboveground biomass; $\mathrm{BGB}=$ belowground biomass; $\mathrm{SBD}=$ soil bulk density; $\mathrm{SM}=$ soil moisture.

\begin{tabular}{|c|c|c|c|c|c|c|c|c|c|}
\hline \multirow[b]{2}{*}{ Variable } & \multirow[b]{2}{*}{$n$} & \multirow[b]{2}{*}{ Mean } & \multirow[b]{2}{*}{ SD } & \multicolumn{3}{|c|}{$\begin{array}{l}\text { Variables used to } \\
\text { build the tree models }\end{array}$} & \multicolumn{3}{|c|}{$\begin{array}{l}\text { Variables selected } \\
\text { finally }\end{array}$} \\
\hline & & & & SIC & SOC & SIC/STC & SIC & SOC & SIC/STC \\
\hline Alt & 80 & 2692 & 1692.4 & Yes & & Yes & & & \\
\hline MAT & 79 & -1.1 & 2.42 & Yes & Yes & Yes & Yes & & Yes \\
\hline GST & 75 & 8.8 & 4.63 & Yes & Yes & Yes & & & \\
\hline MAP & 79 & 384.0 & 113.66 & Yes & Yes & Yes & Yes & & \\
\hline GSP & 75 & 270.5 & 63.01 & Yes & Yes & Yes & & Yes & \\
\hline PE & 75 & 432.0 & 92.30 & Yes & Yes & Yes & Yes & Yes & \\
\hline $\mathrm{AE}$ & 75 & 321.7 & 59.81 & Yes & Yes & Yes & & & \\
\hline $\mathrm{AP} / \mathrm{PE}$ & 74 & 1.0 & 0.43 & Yes & & Yes & & & \\
\hline VT & 81 & - & - & Yes & Yes & Yes & & Yes & \\
\hline AGB & 77 & 96.4 & 59.41 & Yes & Yes & Yes & & Yes & Yes \\
\hline BGB & 73 & 113.3 & 1515.15 & Yes & Yes & Yes & & & \\
\hline $\mathrm{pH}$ & 81 & 6.88 & 0.563 & Yes & & Yes & Yes & & Yes \\
\hline SBD & 81 & 1.11 & 0.315 & Yes & & & & & \\
\hline SM & 76 & 15.2 & 15.27 & Yes & & Yes & Yes & & Yes \\
\hline
\end{tabular}

\subsection{Different controls on the large scale patterns of SIC and SOC}

According to the tree models, carbonates and organic carbon in the topsoil were affected by different factors. The pattern of SIC could be well explained by climate, soil physical and chemical properties (including soil $\mathrm{pH}, \mathrm{PE}, \mathrm{MAT}, \mathrm{MAP}$ and SM), while for SOC biotic and climatic factors were predominant (including vegetation type, AGB, PE and GSP).

In our research, soil $\mathrm{pH}$ is the most important factor for explaining the variation of SIC. Importantly, this strong relationship can be related to a decrease in $\mathrm{HCO}_{3}^{-}$due to low $\mathrm{pH}$ as shown by the following equation:

$$
\begin{aligned}
\mathrm{CaCO}_{3} & +2 \mathrm{H}^{+} \leftrightarrow \mathrm{Ca}^{2+}+\mathrm{H}^{+}+\mathrm{HCO}_{3}^{-} \leftrightarrow \mathrm{Ca}^{2+} \\
& +\mathrm{CO}_{2}+\mathrm{H}_{2} \mathrm{O}
\end{aligned}
$$

Acidification induces the equilibrium towards the right, thus decreasing the formation of SIC (Lal and Kimble, 2000; Suarez, 2000). In our study, $42 \%$ of the variation in SIC could be attributed to the differences of soil $\mathrm{pH}$ among the 81 sites. Within different $\mathrm{pH}$ ranges ( $\mathrm{pH}<7.0$ or $\mathrm{pH}>7.0$ ), distinct environmental factors drive the finer pattern of SIC, indicating that SIC is influenced by different processes depending on soil $\mathrm{pH}$. As $\mathrm{pH}$ increases above the threshold, thermal factors have stronger effects than other factors, showing negative relationships with SIC. This is consistent with results reported in other studies (Mi et al., 2008; Yang et al., 2010a). Temperature affects $\mathrm{CaCO}_{3}$ equilibria through its effects on $\mathrm{CaCO}_{3}$ solubility, evapotranspiration and leaching (Lal and Kimble, 2000), but it is not appropriate to attribute variation in SIC to temperature in our research. Temperature af- fects biological activity especially soil respiration positively (Davidson and Janssens, 2006; Raich and Schlesinger, 1992), which increases soil $\mathrm{CO}_{2}$ partial pressure. Moreover, in our study region, temperature decreases with increasing elevation. Consequently, higher temperature means lower altitude and thus in turn higher $\mathrm{CO}_{2}$ partial pressure. High $\mathrm{CO}_{2}$ partial pressure inhibits the formation of carbonates in the topsoil (Eq. 1), leading to negative relationships between SIC and thermal factors. In the areas with $\mathrm{pH}<7.0$, SIC tends to be in a form of dissolved bicarbonate and the leaching process becomes more important, consequently water condition factors like MAP and SM entered the model. However, the result of our research showing that lower MAP is corresponding to lower SIC is in contrast to some other studies, in which SIC shows a decreasing trend along precipitation gradients (Mi et al., 2008; Nordt et al., 2000; Wang et al., 2010; Yang et al., 2010a). Further analysis suggested that most of those sites with MAP $<465 \mathrm{~mm}$ were distributed in the Inner Mongolia, while those sites with MAP $>465$ were all located on the Tibetan Plateau. Thus the positive SIC-precipitation relationship in this study may be caused by other confounding factors that were different between the two regions.

For SOC, steppe soils present much lower organic carbon contents than meadow soils. As the main resource of SOC, vegetation determines quantity, quality and distribution of SOC (Jobbagy and Jackson, 2000; Poeplau et al., 2011; Quideau et al., 2001). In Chinese grasslands, meadow has higher productivity than steppe (Ma et al., 2010; Ni, 2004), which means more organic materials input into meadow soils compared to steppe sites. Moreover, alpine meadows occur under cold and humid environments. Consequently, 


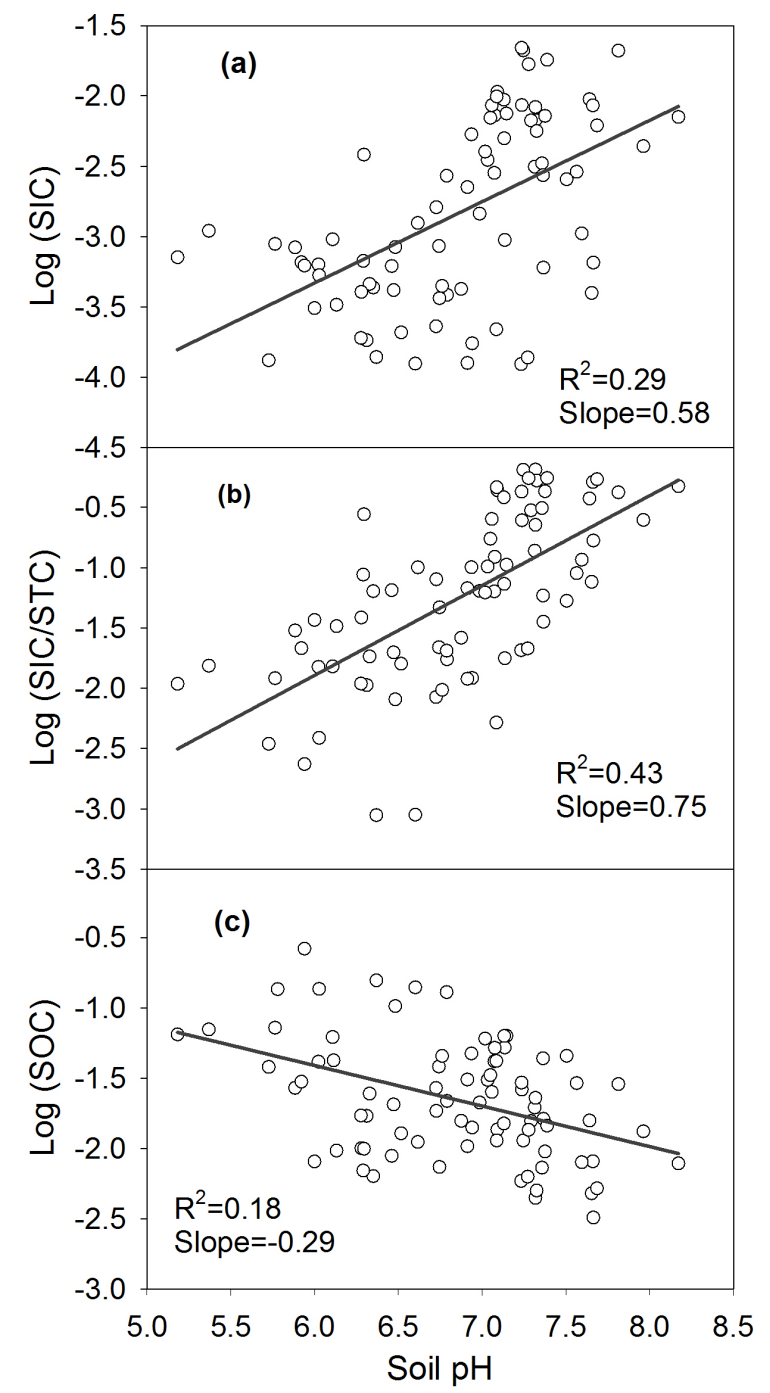

Fig. 4. Linear relationships of SIC (a), SIC/STC (b) and SOC (c) with soil $\mathrm{pH}$ value in the topsoil. All regression lines were significant $(P<0.05)$.

decomposition of SOC is limited by temperature and temporal water saturation (Davidson and Janssens, 2006; Jobbagy and Jackson, 2000; Baumann et al., 2009). These two interrelated processes (i.e. high input and low decomposition) both contribute to higher SOC in the meadow ecosystem. Within different vegetation types, finer patterns of SOC are driven by different processes. In meadows, AGB shows a strong effect on SOC. Because AGB reflects vegetation productivity (LeBauer and Treseder, 2008; Ni, 2004), the latter influences SOC content of the meadow sites by controlling the input of organic materials. When AGB increases above the threshold, PE has a negative relationship with SOC. Although high temperature may stimulate plant production as temperature is an important limiting factor for vegetation growth in the alpine meadow (Piao et al., 2006), temperature-induced higher SOC decomposition overrides the resulting increase in $\mathrm{C}$ inputs, thus leading to a decrease of SOC. On the other hand, in steppe ecosystems, water conditions are the primary constraint to vegetation productivity (Heisler-White et al., 2008; Jobbagy et al., 2002; Sala et al., 1988). High GSP could stimulate plant production and increase soil $\mathrm{C}$ accumulation, thus precipitation is the most important variable in controlling SOC patterns in steppe ecosystems.

\subsection{Decrease in SIC but increase in STC under soil acidification}

Our study provides insights in estimating future change of SIC under the scope of soil acidification scenarios. During the past several decades, parts of Europe and Eastern North America suffered from significant acidification due to acid deposition (Bowman et al., 2008; Galloway et al., 2003). For example, in Europe soil pH decreased between 0.2 to 2 units over the past 17 to $110 \mathrm{yr}$ (Stevens et al., 2009). China also has to face severe soil acidification problems due to increasing energy demand and excessive application of chemical fertilizer (Hicks et al., 2008; Larssen and Carmichael, 2000; Guo et al., 2010). Considering the important role of soil $\mathrm{pH}$ in controlling the pattern of SIC, soil acidification will have a great impact on topsoil's inorganic carbon stocks in the future.

Up to date, no studies have investigated the trend or extent of soil acidification in Chinese grasslands. However, soil $\mathrm{pH}$ records in croplands close to our study region provide circumstantial evidences to approximate the extent of soil acidification. From the 1980 s to the 2000 s, soil pH in croplands on the Loess Plateau and the Tibetan Plateau declined by 0.27 and 0.48 units respectively (Zhou et al., 2009; Guo et al., 2010). Assuming the acidification rate in croplands is the same as that in grasslands and remains the same in the next $20 \mathrm{yr}$, according to our linear regression models, acidification will lead to $30 \%$ and $53 \%$ decrease in SIC in the Inner Mongolian and Tibetan grasslands respectively.

Although acidification leads to a decrease in SIC, carbon stock in the topsoil will not necessarily decline with soil acidification. It can be assumed, that due to accumulation of SOC, STC is likely to rise with increasing acidity, backed up by the negative relationship between soil $\mathrm{pH}$ and $\mathrm{SOC}$ as well as the even faster decline of SIC/STC compared to SIC with decreasing soil $\mathrm{pH}$. There are two ways this pattern can be explained. Firstly, acidification inhibits soil microbial activities and thus the SOC decomposition rate (Francis, 1986). Secondly, N deposition, a major cause of acidification, will lead to an increase of SOC inputs through increasing vegetation productivity (Neff et al., 2002), and may induce a decrease in microbial biomass and oxidase activity (Dalmonech et al., 2010; Fisk and Fahey, 2001; Zak et al., 2008). Both of these will contribute to accumulation of SOC, thus leading to an increase in STC. Moreover, SIC only accounts for a very small proportion of STC on average. Therefore, soil acidification would not make a great impact on soil carbon. 


\subsection{Uncertainty of prediction}

In the present study, the linear regression models with soil $\mathrm{pH}$ as independent variable were used to predict the future change of soil $\mathrm{C}$ under soil acidification scenario. Soil $\mathrm{pH}$ is the most important variable driving the large-scale pattern of SIC and SIC/STC. SOC also has a significant relationship with soil $\mathrm{pH}$. These two facts suggest that our prediction could be helpful in understanding soil $\mathrm{C}$ change with acidification. However, some uncertainties remain in the prediction. The linear regression models were based on spatial relationships between soil $\mathrm{pH}$ and carbon content. Therefore, there may be some bias for predicting temporal soil carbon change using the models. Additionally, we used the acidification data in cropland near our study region since no other data is available to investigate the trend or extent of soil acidification in Chinese grasslands. This may also bring prediction errors.

Another limitation in our models could stem from ignoring the influences of grazing. The direct and indirect impact of grazing on soil parameters, such as bulk density, soil moisture and carbon contents have been described and discussed in various studies (Stavi et al., 2008; Wu et al., 2010; Hafner et al., 2012). At low grazing intensities, concentrated movements of livestock in areas with changing micro-topography on a small spatial scale mostly affect soil properties, often in a very complex way (Trimble and Mendel, 1995; Stavi et al., 2012). Since cattle tracks and pathways are obvious in field, we avoided taking samples from such places to minimize the grazing and other livestock-induced disturbances. Although sampling sites were selected against this background, nomadic pastoralism is ubiquitous in the Inner Mongolian and Tibetan grasslands, and can hardly be completely excluded. However, small-scale grazing variability in our study region may be not as pronounced as in other pasture grassland regions of the world for most of the investigated sites, as especially Kobresia dominated ecosystems have developed very stable felty topsoil horizons (Kaiser, 2004) that have formed during more than $6000 \mathrm{yr}$ of nomadism (Schlütz and Lehmkuhl, 2009). What extent is grazing impacting on soil carbon in our study region is still difficult to quantify.

Further studies are needed to validate the robustness of the relationships between soil carbon and soil $\mathrm{pH}$ at different spatial and temporal scales. In particular, long-term multifactor experiments along environmental gradients might be useful to test these relationships. Moreover, the extents and trends of soil acidification in Chinese grasslands should also be investigated to give a more accurate prediction of soil carbon change in the future.

\section{Conclusions}

Through analyzing the topsoil data of 81 sites at three different depth increments obtained from a regional survey across grasslands in Inner Mongolia and the Tibetan Plateau during
2006-2007, we found that both SIC and SOC in the Tibetan grasslands were significantly higher than those in the Inner Mongolian grasslands. Higher SIC in the Tibetan grasslands may be due to higher LIC derived from parent material and more PIC formation caused by lower $\mathrm{CO}_{2}$ partial pressure, whereas higher SOC in the Tibetan grasslands is caused by higher litter input and lower decomposition rates. At a largescale, SIC and SOC were controlled by different environmental factors. SIC was mainly driven by chemical and physical processes, particularly by soil $\mathrm{pH}$ and other processes depending on soil $\mathrm{pH}$. However, SOC was controlled by biotic processes such as vegetation type. Our results imply that given the acidification rate in Chinese grassland soils in the future, as has been the case in Chinese cropland soils during the past two decades, SIC will decrease by $30 \%$ and $53 \%$ in the Inner Mongolian grasslands and the Tibetan grasslands, respectively, in the next $20 \mathrm{yr}$. However, the negative relationship between soil $\mathrm{pH}$ and SOC suggests that acidification will inhibit decomposition of SOC, and thus will not lead to a significant general loss of carbon from soils in these regions.

Acknowledgements. The authors are grateful to Wenhong Ma, Kuo Yang for assistance with field sample collections, and Biao Zhu for helpful and constructive comments on the previous version of this manuscript. This study was supported by the Program of "One Hundred Talented People" of the Chinese Academy of Sciences (Grant No. KSCX2-YW-Z-0806), the National Natural Science Foundation of China (Grant No. 31025005 and 31021001), National Program on Key Basic Research Project (Grant No. 2010CB950602), and the "Strategic Priority Research Program" of the Chinese Academy of Sciences (Grant No. XDA05050304).

Edited by: M. Dai

\section{References}

Batjes, N.: Total carbon and nitrogen in the soils of the world, Eur. J. Soil Sci., 47, 151-163, 1996.

Baumann, F., He, J. -S., Schmidt, K., Kühn, P., and Scholten, T.: Pedogenesis, permafrost, and soil moisture as controlling factors for soil nitrogen and carbon contents across the Tibetan Plateau, Global Change Biol., 15, 3001-3017, 2009.

Bowman, W. D., Cleveland, C. C., Halada, L., Hresko, J., and Baron, J. S.: Negative impact of nitrogen deposition on soil buffering capacity, Nat. Geosci., 1, 767-770, 2008.

Callesen, I., Liski, J., Raulund-Rasmussen, K., Olsson, M. T., TauStrand, L., Vesterdal, L., and Westman, C. J.: Soil carbon stores in Nordic well-drained forest soils-relationships with climate and texture class, Global Change Biol., 9, 358-370, 2003.

Chatterjee, A., Lal, R., Wielopolski, L., Martin, M. Z., and Ebinger, M. H.: Evaluation of different soil carbon determination methods, Crit. Rev. Plant Sci., 28, 164-178, 2009.

Chinese Academy of Sciences: Vegetation Atlas of China, Science Press, Beijing, 2001. 
Dalmonech, D., Lagomarsino, A., Moscatelli, M. C., Chiti, T., and Valentini, R.: Microbial performance under increasing nitrogen availability in a Mediterranean forest soil, Soil Biol. Biochem., 42, 1596-1606, 2010.

Davidson, E. A. and Janssens, I. A.: Temperature sensitivity of soil carbon decomposition and feedbacks to climate change, Nature, 440, 165-173, 2006.

Eswaran, H., Van den Berg, E., Reich, P., and Kimble, J.: Global soil carbon resources, in: Soils and Global Change, edited by: Lal, R., Kimble, J. M., Levine, E., and Stewart, B. A., CRC/Lewis Publishers, Boca Raton, 27-43, 1995.

Eswaran, H., Reich, P. F., Kimble, J. M., Beinroth, F. H., Padmanabhan, E., and Moncharoen, P.: Global carbon stocks, in: Global Climate Change and Pedogenic Carbonates, edited by: Lal, R., Kimble, J. M., Eswaran, H., and Stewart, B. A., CRC Press, Boca Raton, Florida, 15-25, 2000.

Fang, J. Y., Piao, S. L., Tang, Z. Y., Peng, C. H., and Wei, J.: Interannual variability in net primary production and precipitation, Science, 293, 1723, doi:10.1126/science.293.5536.1723a, 2001.

FAO: Guidelines for soil description, 4th Edn., FAO, Rome, 2006.

Feng, Q., Endo, K. N., and Cheng, G. D.: Soil carbon in desertified land in relation to site characteristics, Geoderma, 106, 21-43, 2002.

Fisk, M. C. and Fahey, T. J.: Microbial biomass and nitrogen cycling responses to fertilization and litter removal in young northern hardwood forests, Biogeochemistry, 53, 201-223, 2001.

Francis, A. J.: The ecological effects of acid deposition II: acid-rain effects on soil and aquatic microbial processes, Cell. Mol. Life Sci., 42, 455-465, 1986.

Franzluebbers, A. J. and Stuedemann, J. A.: Surface soil changes during twelve years of pasture management in the Southern Piedmont USA, Soil Sci. Soc. Am. J., 74, 2131-2141, 2010.

Galloway, J. N., Aber, J. D., Erisman, J. W., Seitzinger, S. P., Howarth, R. W., Cowling, E. B., and Cosby, B. J.: The nitrogen cascade, BioScience, 53, 341-356, 2003.

Guo, J. H., Liu, X. J., Zhang, Y., Shen, J. L., Han, W. X., Zhang, W. F., Christie, P., Goulding, K. W. T., Vitousek, P. M., and Zhang, F. S.: Significant acidification in major Chinese croplands, Science, 327, 1008-1010, 2010.

Hafner, S., Unteregelsbacher, S., Seeber, E., Lena, B., Xu, X., Li, X., Guggenberger, G., Miehe, G., and Kuzyakov, Y.: Effect of grazing on carbon stocks and assimilate partitioning in a Tibetan montane pasture revealed by ${ }^{13} \mathrm{CO}_{2}$ pulse labeling, Global Change Biol., 18, 528-538, 2012.

He, J.-S., Wang, X., Flynn, D. F. B., Wang, L., Schmid, B., and Fang, J.: Taxonomic, phylogenetic, and environmental trade-offs between leaf productivity and persistence, Ecology, 90, 27792791, 2009.

Heisler-White, J. L., Knapp, A. K., and Kelly, E. F.: Increasing precipitation event size increases aboveground net primary productivity in a semi-arid grassland, Oecologia, 158, 129-140, 2008.

Hicks, W. K., Kuylenstierna, J. C. I., Owen, A., Dentener, F., Seip, H. M., and Rodhe, H.: Soil sensitivity to acidification in Asia: status and prospects, Ambio: A Journal of the Human Environment, 37, 295-303, 2008.

IUSS Working Group WRB: World reference base for soil resources 2006, FAO Rome, World Soil Resourses Reports. No. 103, 2006.

Jobbagy, E. G. and Jackson, R. B.: The vertical distribution of soil organic carbon and its relation to climate and vegetation, Ecol.
Appl., 10, 423-436, 2000.

Jobbagy, E. G., Sala, O. E., and Paruelo, J. M.: Patterns and controls of primary production in the Patagonian steppe: a remote sensing approach, Ecology, 83, 307-319, 2002.

Kaiser, K.: Pedogeomorphological transect studies in Tibet: implications for landscape history and present-day dynamics, Prace Geograficzne, 200, 147-165, 2004.

Kang, L., Han, X. G., Zhang, Z. B., and Sun, O. J.: Grassland ecosystems in China: review of current knowledge and research advancement, Philos. T. R. Soc. B, 362, 997-1008, 2007.

Kato, T., Tang, Y., Gu, S., Hirota, M., Du, M., Li, Y., and Zhao, $\mathrm{X}$.: Temperature and biomass influences on interannual changes in $\mathrm{CO}_{2}$ exchange in an alpine meadow on the Qinghai-Tibetan Plateau, Global Change Biol., 12, 1285-1298, 2006.

Kirschbaum, M. U. F.: The temperature dependence of soil organic matter decomposition, and the effect of global warming on soil organic C storage, Soil Biol. Biochem., 27, 753-760, 1995.

Körner, C.: Alpine Plant Life: Functional Plant Ecology of High Mountain Ecosystems, Springer Berlin, Heidelberg, 2003.

Lal, R.: Soil carbon sequestration impacts on global climate change and food security, Science, 304, 1623-1627, 2004a.

Lal, R.: Agricultural activities and the global carbon cycle, Nutr. Cycl. Agroecosys, 70, 103-116, 2004b.

Lal, R.: Carbon sequestration, Philos. T. R. Soc. B, 363, 815-830, 2008.

Lal, R. and Kimble, J. M.: Pedogenic carbonates and the global carbon cycle, in: Global Climate Change and Pedogenic Carbonates, edited by: Lal, R., Kimble, J. M., Eswaran, H., and Stewart, B. A., CRC Press, Boca Raton, Florida, 1-14, 2000.

Larssen, T. and Carmichael, G. R.: Acid rain and acidification in China: the importance of base cation deposition, Environ. Pollut., 110, 89-102, 2000.

LeBauer, D. S. and Treseder, K. K.: Nitrogen limitation of net primary productivity in terrestrial ecosystems is globally distributed, Ecology, 89, 371-379, 2008.

Li, Z. P., Han, F. X., Su, Y., Zhang, T. L., Sun, B., Monts, D. L., and Plodinec, M. J.: Assessment of soil organic and carbonate carbon storage in China, Geoderma, 138, 119-126, 2007.

Liao, Q. L., Zhang, X. H., Li, Z. P., Pan, G. X., Smith, P., Jin, Y., and $\mathrm{Wu}, \mathrm{X}$. M.: Increase in soil organic carbon stock over the last two decades in China's Jiangsu Province, Global Change Biol., 15, 861-875, 2009.

Ma, W. H., He, J. -S., Yang, Y. H., Wang, X. P., Liang, C. Z., Anwar, M., Zeng, H., Fang, J. Y., and Schmid, B.: Environmental factors covary with plant diversity-productivity relationships among Chinese grassland sites, Global Ecol. Biogeogr., 19, 233243, 2010.

Mi, N., Wang, S. Q., Liu, J. Y., Yu, G. R., Zhang, W. J., and Jobbaagy, E.: Soil inorganic carbon storage pattern in China, Global Change Biol., 14, 2380-2387, 2008.

Mikhailova, E. A. and Post, C. J.: Effects of land use on soil inorganic carbon stocks in the Russian Chernozem, J. Environ. Qual., 35, 1384-1388, 2006.

Monger, H. C. and Gallegos, R. A.: Biotic and abiotic processes and rates of pedogenic carbonate accumulation, in: Global Climate Change and Pedogenic Carbonates, edited by: Lal, R., Kimble, J. M., Eswaran, H., and Stewart, B. A., CRC Press, Boca Raton, Florida, 2000. 
Neff, J. C., Townsend, A. R., Gleixner, G., Lehman, S. J., Turnbull, J., and Bowman, W. D.: Variable effects of nitrogen additions on the stability and turnover of soil carbon, Nature, 419, 915-917, 2002.

$\mathrm{Ni}$, J.: Carbon storage in grasslands of China, J. Arid. Environ., 50, 205-218, 2002.

$\mathrm{Ni}$, J.: Estimating net primary productivity of grasslands from field biomass measurements in temperate northern China, Plant. Ecol., 174, 217-234, 2004.

Nordt, L. C., Wilding, L. P., and Drees, L. R.: Pedogenic carbonate transformations in leaching soil system: implication for the global C cycle, in: Global Climate Change and Pedogenic Carbonates, edited by: Lal, R., Kimble, J. M., Eswaran, H., and Stewart, B. A., CRC Press, Boca Raton, Florida, 43-64, 2000.

Ouyang, X. J., Zhou, G. Y., Huang, Z. L., Liu, J. X., Zhang, D. Q., and Li, J.: Effect of simulated acid rain on potential carbon and nitrogen mineralization in forest soils, Pedosphere, 18, 503-514, 2008.

Piao, S. L., Fang, J. Y., and He, J. -S.: Variations in vegetation net primary production in the Qinghai-Xizang Plateau, China, from 1982 to 1999, Climatic Change, 74, 253-267, 2006.

Poeplau, C., Don, A., Vesterdal, L., Leifeld, J., Van Wesemael, B. A. S., Schumacher, J., and Gensior, A.: Temporal dynamics of soil organic carbon after land-use change in the temperate zone: carbon response functions as a model approach, Global Change Biol., 17, 2415-2427, 2011.

Qian, S. S.: Environmental and ecological statistics with R, Chapman \& Hall, 2009.

Quideau, S. A., Chadwick, O. A., Benesi, A., Graham, R. C., and Anderson, M. A.: A direct link between forest vegetation type and soil organic matter composition, Geoderma, 104, 41-60, 2001.

R Development Core Team: R: a language and environment for statistical computing, R Foundation for Statistical Computing Vienna, Austrilia, 2011.

Raich, J. W. and Schlesinger, W. H.: The global carbon dioxide flux in soil respiration and its relationship to vegetation and climate, Tellus B, 44, 81-99, 1992.

Rockström, J., Steffen, W., Noone, K., Persson, A., Chapin, F. S., Lambin, E. F., Lenton, T. M., Scheffer, M., Folke, C., Schellnhuber, H. J., Nykvist, B., de Wit, C. A., Hughes, T., van der Leeuw, S., Rodhe, H., Sorlin, S., Snyder, P. K., Costanza, R., Svedin, U., Falkenmark, M., Karlberg, L., Corell, R. W., Fabry, V. J., Hansen, J., Walker, B., Liverman, D., Richardson, K., Crutzen, P., and Foley, J. A.: A safe operating space for humanity, Nature, 461, 472-475, 2009.

Sala, O. E., Parton, W. J., Joyce, L. A., and Lauenroth, W. K.: Primary production of the central grassland region of the United States, Ecology, 69, 40-45, 1988.

Schlesinger, W. H. and Andrews, J. A.: Soil respiration and the global carbon cycle, Biogeochemistry, 48, 7-20, 2000.

Schlütz, F., and Lehmkuhl, F.: Holocene climatic change and the nomadic Anthropocene in Eastern Tibet: palynological and geomorphological results from the Nianbaoyeze Mountains, Quaternary Sci. Rev., 28, 1449-1471, 2009.

Schulze, E. D. and Freibauer, A.: Carbon unlocked from soils, Nature, 437, 205-206, 2005.

Scurlock, J. M. O. and Hall, D. O.: The global carbon sink: a grassland perspective, Global Change Biol., 4, 229-233, 1998.
Song, G. H., Li, L. Q., Pan, G. X., and Zhang, Q.: Topsoil organic carbon storage of China and its loss by cultivation, Biogeochemistry, 74, 47-62, 2005.

Stavi, I., Ungar, E. D., Lavee, H., and Sarah, P.: Grazing-induced spatial variability of soil bulk density and content of moisture, organic carbon and calcium carbonate in a semi-arid rangeland, Catena, 75, 288-296, 2008.

Stavi, I., Lavee, H., Ungar, E., and Sarah, P.: Grazing-induced modification of a semi-arid rangeland from a two-phase to a threephase mosaic geo-ecosystem, Arid Land Research and Management, 26, 79-83, 2012.

Stevens, C. J., Dise, N. B., and Gowing, D. J.: Regional trends in soil acidification and exchangeable metal concentrations in relation to acid deposition rates, Environ. Pollut., 157, 313-319, 2009.

Suarez, D. L.: Impact of agriculture on $\mathrm{CO}_{2}$ as affected by changes in inorganic carbon, in: Global Climate Change and Pedogenic Carbonates, edited by: Lal, R., Kimble, J. M., Eswaran, H., and Stewart, B. A., CRC Press, Boca Raton, Florida, 257-272, 2000.

Thornthwaite, C. W.: An approach toward a rational classification of climate, Geogr. Rev., 38, 55-94, 1948.

Treseder, K. K.: Nitrogen additions and microbial biomass: a metaanalysis of ecosystem studies, Ecol. Lett., 11, 1111-1120, 2008.

Trimble, S. W. and Mendel, A. C.: The cow as a geomorphic agent-a critical review, Geomorphology, 13, 233-253, 1995.

Trumbore, S. E. and Czimczik, C. I.: An uncertain future for soil carbon, Science, 321, 1455-1456, 2008.

Valentini, R., Matteucci, G., Dolman, A. J., Schulze, E. D., Rebmann, C., Moors, E. J., Granier, A., Gross, P., Jensen, N. O., Pilegaard, K., Lindroth, A., Grelle, A., Bernhofer, C., Grunwald, T., Aubinet, M., Ceulemans, R., Kowalski, A. S., Vesala, T., Rannik, U., Berbigier, P., Loustau, D., Guomundsson, J., Thorgeirsson, H., Ibrom, A., Morgenstern, K., Clement, R., Moncrieff, J., Montagnani, L., Minerbi, S., and Jarvis, P. G.: Respiration as the main determinant of carbon balance in European forests, Nature, 404, 861-865, 2000.

Vitousek, P. M.: Beyond global warming: ecology and global change, Ecology, 75, 1861-1876, 1994.

Wang, W. and Fang, J.: Soil respiration and human effects on global grasslands, Global Planet. Change, 67, 20-28, 2009.

Wang, Y. G., Li, Y., Ye, X. H., Chu, Y., and Wang, X. P.: Profile storage of organic/inorganic carbon in soil: from forest to desert, Sci. Total Environ., 408, 1925-1931, 2010.

Wu, H. B., Guo, Z. T., and Peng, C. H.: Distribution and storage of soil organic carbon in China, Global Biogeochem. Cy., 17, 1048, doi:10.1029/2001GB001844, 2003.

Wu, H. B., Guo, Z. T., Gao, Q., and Peng, C. H.: Distribution of soil inorganic carbon storage and its changes due to agricultural land use activity in China, Agr. Ecosyst. Environ., 129, 413-421, 2009.

Wu, G.-L., Liu, Z.-H., Zhang, L., Chen, J.-M., and Hu, T.-M.: Longterm fencing improved soil properties and soil organic carbon storage in an alpine swamp meadow of western China, Plant. Soil, 332, 331-337, 2010.

Wynn, J. G., Bird, M. I., Vellen, L., Grand-Clement, E., Carter, J., and Berry, S. L.: Continental-scale measurement of the soil organic carbon pool with climatic, edaphic, and biotic controls, Global Biogeochem. Cy., 20, GB1007, doi:10.1029/2005GB002576, 2006. 
Xie, Z. B., Zhu, J. G., Liu, G., Cadisch, G., Hasegawa, T., Chen, C. M., Sun, H. F., Tang, H. Y., and Zeng, Q.: Soil organic carbon stocks in China and changes from 1980s to 2000s, Global Change Biol., 13, 1989-2007, 2007.

Xiong, Y. and Li, Q. D.: Soils of China, Science Press, Beijing, 1987 (in Chinese).

Yang, Y. H., Fang, J. Y., Tang, Y. H., Ji, C. J., Zheng, C. Y., He, J.S., and Zhu, B. A.: Storage, patterns and controls of soil organic carbon in the Tibetan grasslands, Global Change Biol., 14, 15921599, 2008.

Yang, Y. H., Fang, J. Y., Ji, C. J., Ma, W. H., Su, S. S., and Tang, Z. Y.: Soil inorganic carbon stock in the Tibetan alpine grasslands, Global Biogeochem. Cy., 24, GB4022, doi:10.1029/2010GB003804, 2010a.
Yang, Y. H., Fang, J. Y., Ma, W. H., Smith, P., Mohammat, A., Wang, S. P., and Wang, W.: Soil carbon stock and its changes in northern China's grasslands from 1980s to 2000s, Global Change Biol., 16, 3036-3047, 2010b.

Yu, D. S., Shi, X. Z., Wang, H., Sun, W. X., Chen, J. M., Liu, Q. H., and Zhao, Y. C.: Regional patterns of soil organic carbon stocks in China, J. Environ. Manage., 85, 680-689, 2007.

Zak, D. R., Holmes, W. E., Burton, A. J., Pregitzer, K. S., and Talhelm, A. F.: Simulated atmospheric $\mathrm{NO}_{3}^{-}$deposition increases soil organic matter by slowing decomposition, Ecol. Appl., 18, 2016-2027, 2008.

Zhou, Z., Du, S., and Liu, G.: Acidification of surface soil in croplands in the semiarid middle Tibet Plateau, China, 2009 International Conference on Environmental Science and Information Application Technology, 2009, 209-212, 2009. 